\title{
Economics of Flexible Versus Conservative Stocking Strategies to Manage Climate Variability Risk
}

\author{
L. Allen Torell, ${ }^{1}$ Subramanian Murugan, ${ }^{2}$ and Octavio A. Ramirez ${ }^{3}$
}

Authors are ${ }^{1}$ Professor and ${ }^{2}$ former Research Assistant, Department of Agricultural Economics and Agricultural Business, New Mexico State University, Las Cruces, NM 88003, USA; and ${ }^{3}$ Professor and Head, Department of Agricultural and Applied Economics, University of Georgia, Athens, GA 30602, USA.

\begin{abstract}
Recommended strategies for dealing with drought include maintaining a conservative stocking rate, maintaining grazing flexibility by having yearlings as one of multiple enterprises on the ranch, and leaving a significant amount of herbaceous production at the end of the grazing season. We perform an economic analysis of these grazing strategies using a bio-economic multiperiod linear programming model with variable annual forage production and beef prices. We evaluate the economics of conservative versus flexible grazing where stock numbers are adjusted to match forage conditions. The deterministic model estimates that a flexible grazing strategy could nearly double net returns relative to a conservative strategy, but realizing this substantial economic potential means higher production costs, and it depends on a quality climate forecast that is not currently available. Maintaining grazing flexibility was determined to be very important for managing variable forage conditions, and its importance increased with the level of variability. Without annual variation in forage production, over $80 \%$ of available forage would optimally be allocated to cow-calf production. As forage variability increased to levels observed on the arid rangelands of the western United States, a 50:50 forage allocation between cow-calf and yearling enterprises was found to be optimal, but optimal cow numbers decreased over time as dry conditions force herd reductions. As compared to a cow-calf ranch only, adding flexible yearling enterprises increased average annual net ranch returns by $14 \%$ with conservative stocking and by up to $66 \%$ with flexible grazing. Herd expansion beyond a conservative level should occur with yearlings because adjusting cow numbers is too expensive relative to the potential short-term gain, even if forage conditions are known with certainty.
\end{abstract}

\section{Resumen}

Las estrategias recomendadas para los periodos de sequia incluyen el uso de carga animal conservadora, el uso de recría de terneros como una de las múltiples actividades del establecimiento para mantener la flexibilidad de pastoreo, y la reserva de una buena cantidad de forraje en pie. Se realizó un análisis de dichas estrategias utilizando un modelo bio-económico de múltiples periodos con programación lineal y con producciones anuales de forraje y precios de carne variables. Se evaluaron los resultados económicos del pastoreo conservador versus flexible en el que el número de animales se ajusta de acuerdo a las condiciones del forraje. El modelo determínistico estimó que una estrategia de pastoreo flexible podría casi duplicar el ingreso neto comparado con una estrategia conservadora, pero la concreción de este potencial económico sustancial implica mayores costos de producción y depende de la calidad de pronósticos climáticos que no están disponibles por el momento. Se determinó que mantener la flexibilidad de pastoreo es muy importante para manejar condiciones de forraje variables y que su importancia aumenta con el nivel de variabilidad de la producción forrajera. Sin variación anual en la producción de forraje más del $80 \%$ del forraje disponible sería alocado óptimamente a la actividad de cría. A medida que la variabilidad en la producción de forraje alcanzó niveles observados en pastizales áridos del oeste de los Estados Unidos una proporción 50:50 de asignación de forraje a las actividades de cría y recría resultó ser óptima, sin embargo el numero de vientres decreció con el tiempo por reducciones en el rodeo forzadas por condiciones se sequía. Comparado con un establecimiento de cría, la incorporación de actividades flexibles de recría de terneros generó un aumento de ingresos netos del establecimiento del $14 \%$ con cargas conservadoras y de hasta el $66 \%$ con pastoreo flexible. La expansión del rodeo más allá de los niveles de carga conservadoras debería realizarse con recría de terneros dado que el ajuste del número de vientres es demasiado oneroso comparado con las ganancias de corto plazo, aun conociendo con certidumbre las condiciones de forraje.

Key Words: Bouteloua gracilis, climate forecast, drought, grazing flexibility, linear programming, stocking strategies

\section{INTRODUCTION}

Rangeland livestock producers face two major types of risk: prices and weather. Futures and options tools are available to help manage price risk (Agricultural Marketing Resource

Research was supported by the New Mexico State University Agricultural Experiment Station. Correspondence: L. Allen Torell, Dept of Agricultural Economics, New Mexico State University, PO Box 30003, MSC 3169, Las Cruces, NM 88003, USA. Email: atorell@nmsu.edu

Manuscript received 30 September 2009; manuscript accepted 29 March 2010.
Center 2007), but fluctuations in seasonal and annual forage production remain ongoing and widespread problems. Dry periods create financial hardship and management problems for people throughout the world.

Livestock producers have generally endured drought by reducing livestock numbers, leasing forage, temporarily grazing rangelands beyond their capacities, and increasing supplemental feeding. Stafford Smith (1992) suggests that successful range managers in Australia have coped with climate variability by pursuing some combination of two management approaches. 
The first approach maintains a conservative stocking rate so that destocking is rarely necessary. The major cost of this strategy is the underutilization of the forage resource and relatively low economic returns during nondrought periods. Holechek et al. (2004) recommend conservative stocking strategies, and contend there is little economic benefit from heavier use rates. Yet, the opportunity cost of conservative stocking may exceed benefits when drought occurs. Riechers et al. (1989) found average annual net returns increased as stocking rate increased. Similarly, Martin (1975) budgeted net annual livestock returns for desert ranches in southern Arizona and concluded that profits continued to increase with increasing stocking rate over a range from $20 \%$ below the long-term average up to the average level stocked over the 1941-1970 study period.

The second drought management strategy described by Stafford Smith (1992) aims to anticipate and follow fluctuating annual forage production levels by building stock levels during favorable years and destocking quickly during dry periods. This strategy has been called flexible, opportunistic, or tracking and should outperform conservative stocking as it capitalizes on favorable years but avoids the economic and environmental consequences of overstocking. Simulation studies in Australia support this hypothesis. Ash et al. (2000) estimated an $18 \%$ production advantage with flexible stocking rates, and the relative advantage of flexible stocking increased with increasing variability in rainfall. Conversely, Campbell et al. (2000) found for communal herds in Zimbabwe conservative stocking strategies yielded higher economic returns when the cost of livestock mortality and public funds for rebuilding communal herds were considered.

Stafford Smith et al. (2000) found relative profitability to be market-dependent with flexible strategies being more profitable relative to the constant strategy as livestock prices rise. However, the variability of annual net returns increases for flexible stocking and with higher average stocking rates (Riechers et al. 1989; Stafford Smith et al. 2000). Campbell et al. (2006) noted several environmental and economic conditions that would favor conservative over opportunistic grazing strategies, including unpredictable environmental variation, lack of resiliency in the system, high discount rates, low annual variability in livestock prices, when sell-offs have little influence on livestock prices, or when ungrazed forage measurably contributes to improved soil conditions and future productivity.

Optimal herd mix is another important consideration in stocking rate decisions because different animal classes offer different degrees of flexibility. A common recommendation has been that ranges should be stocked with a basic breeding herd that is not detrimental to rangeland during drought years and any excess forage produced in average or above-average years would be utilized by purchased stocker animals or carry-over yearlings (Holechek et al. 2004). Hart and Carpenter (2005) recommend that in areas prone to drought, breeding herds should constitute no more than $50 \%$ to $70 \%$ of the total carrying capacity of the ranch during normal years. They further recommend that forage reserves of $336 \mathrm{~kg} \cdot \mathrm{ha}^{-1}$ to $560 \mathrm{~kg} \cdot \mathrm{ha}^{-1}$ remain at the end of the grazing period for shortgrass prairie rangeland.

In this article we evaluate the economics of following alternative livestock production and marketing strategies in the face of climate variability on shortgrass prairie rangeland. The analysis does not provide insight as to how one would successfully predict forage conditions and implement a flexible grazing strategy; rather, we estimate the economic benefits if one were able to do so. We evaluate the economic importance of maintaining grazing flexibility with yearling animals and determine what part of the variation in net annual returns can be attributed to variation in annual forage production.

\section{STUDY SITE}

This study was conducted using the production and economic characteristics of New Mexico State University's Corona Range and Livestock Research Center (CRLRC), near Corona, New Mexico (lat $34^{\circ} 15^{\prime} \mathrm{N}$, long $105^{\circ} 24^{\prime} \mathrm{W}$ ). The ranch covers 11381 ha at an elevation of approximately $1900 \mathrm{~m}$. Mean annual precipitation is $370 \mathrm{~mm}$, most of which occurs in July and August as high intensity, short duration convectional thunderstorms (Torell et al. 2008). Blue grama (Bouteloua gracilis [Kunth in H.B.K.] Lag.ex Griffiths) is the primary and dominant forage species, and broom snakeweed (Gutierrezia sarothrae [Pursh] Britt. and Rusby) and pinyon-juniper are invading woody species (McDaniel et al. 1997).

\section{ECONOMIC MODEL}

From the perspective of a profit-maximizing ranch manager, the stocking rate problem can be viewed as a dynamic constrained optimization problem. The bioeconomic model is quantified using a General Algebraic Modeling System (GAMS; Brooke et al. 2005) multiperiod linear programming (LP) model that has been used elsewhere with various modifications (Torell et al. 2002; Stillings et al. 2003; Tanaka et al. 2007). As detailed by Torell et al. (2002, fig. 1), the model is ultimately constrained by available land (forage) and cash with numerous equations to transfer animals, forage, and cash between years and seasons. In this application variable seasonal and annual forage supply and demand is explicitly considered.

\section{Objective Function}

The objective of the manager is assumed to be the selection of range management practices and grazing strategies that maximize the net present value (NPV) of discounted net annual ranch returns over a 40-yr planning horizon, subject to various resource constraints. A 7\% discount rate was used to discount future economic returns. This rate provides an estimated historical $4 \%$ real rate of return on investment plus a $3 \%$ risk premium deemed appropriate for agricultural investments (Agricultural and Applied Economics Association 2000).

Economic data used in the model were primarily from a Standardized Performance Analysis (SPA) financial analysis (McGrann 1996) conducted for the CRLRC and other New Mexico ranches during 2005 and 2006. The SPA analysis provided an annual itemized accounting of production costs and production rates by enterprise and provided a comparison to other New Mexico ranches also conducting the SPA assessment. Production costs and production rates for the New Mexico State University research ranch were similar to 
other New Mexico ranches once research-related expenses were subtracted. Table 1 summarizes key assumptions about production rates and costs. Murugan (2007) provides additional detail about cost calculations.

Calculated net annual returns are defined as gross returns minus forage harvest costs, animal raising costs, loan repayment costs, and fixed costs. It is a residual amount left to pay a return to capital investment and to provide a return for management and risk. Similar to other western ranches, the investment is substantial, with the 2003 market value of the CRLRC estimated to be over $\$ 2$ million (Torell and Rimbey 2005).

It is recognized that during drought few opportunities may exist to purchase outside forage on an as-needed basis, because drought and forage shortages are generally widespread. To account for this, we considered two different price situations for leased forage: \$20 and \$50 per Animal Unit Month (AUM). The lower price reflects a normal full-price forage lease where local forage can be leased with full care provided for displaced animals or when economically optimal for herd expansion. The $\$ 20 \cdot \mathrm{AUM}^{-1}$ price was used during normal or favorable precipitation conditions. The $\$ 50 \cdot \mathrm{AUM}^{-1}$ rate reflects the situation where displaced cattle would be shipped a considerable distance or fed relatively low quality roughage during drought.

Annual fixed expenses that do not vary with the number of animals produced included fixed labor (\$14868), ranch maintenance $(\$ 20000)$, and public and state land grazing fees (\$9053) for a total annual amount of $\$ 43921$. Some costs occur because livestock reside on rangeland. These forage harvest costs include brush and weed control, fence and water maintenance, moving cattle between pastures, and other activities related to providing and harvesting forage. Based largely on a grazing cost study by Torell et al. (1993), forage harvest cost was assumed to average $\$ 3.38 \cdot \mathrm{ha}^{-1}$ after adjusting to a real 2005 cost basis. As implied by linear programming methods, this expense can be foregone in the model by not harvesting forage from selected acreages. With a fixed grazing cost per hectare, the implied grazing cost per AUM varies with the realized level of rangeland productivity. If, as an example, annual herbage production was $650 \mathrm{~kg} \cdot \mathrm{ha}^{-1}$ (0.87 harvestable AUM $\cdot \mathrm{ha}^{-1}$ ), forage cost would be $\$ 3.91$. $\mathrm{AUM}^{-1}$. If forage production was only $400 \mathrm{~kg} \cdot \mathrm{ha}^{-1}(0.18$ harvestable $\mathrm{AUM} \cdot \mathrm{ha}^{-1}$ ), the implied cost would be $\$ 19.17 \cdot \mathrm{AUM}^{-1}$. Because forage costs per AUM increase with reduced herbaceous production, it was not always profitable to harvest forage from relatively unproductive areas and the model allowed areas to remain ungrazed.

In addition to the SPA financial analysis, yearling enterprise budgets were also used to define selected costs (Marousek 2005; Smathers and Rimbey 2006). Additional costs not shown in Table 1, but included in the model, are animal purchase costs and interest charges on purchased yearlings, carryover yearlings, and brood animals. These costs vary by year depending on beef prices.

Annual ranch income and optimal production strategies are greatly influenced by livestock prices. To consider the effect of beef price variation on ranch returns and optimal production strategies, a Monte Carlo analysis was used. Different beef prices were generated for each of 100 model iterations over a 40-yr planning horizon (Torell et al. 2002). Real 2005 livestock prices were stochastic exogenous variables in the LP model, and the model maximizes profit with knowledge about the 40-yr price history. Price seasonality for the typical purchase and sale months for different animal classes was considered in the analysis.

The starting point of the beef price cycle was randomly assigned at the beginning of each iteration. Beef prices used in the LP model fluctuated randomly, but explicitly consider the linkage in prices between years and the relationship in prices between livestock classes. The peaks and valleys of the price series were different for each $40-y r$ price scenario with an approximate 12 -yr cycle from peak to peak. Tucumcari, New Mexico, bull sale data indicate that young bulls sell for slightly over twice that of bred cows and this relationship was assumed in the model. Brood cows were sold at cull prices, whereas cow purchases were at the considerably higher bred cow price. Table 2 summarizes average prices and variation in prices for various livestock classes used in the LP model.

\section{Forage Equations}

Because annual variation in herbaceous production is closely tied to annual variation in rainfall, a detailed analysis of climate and forage production patterns and relationships on the CRLRC was required. As noted by Sneva and Hyder (1962), precipitation frequency distributions for semiarid and arid regions are usually not normally distributed but instead show a noticeable right skewness. This skewness implies that, while rainfall variability is limited at lower levels, extraordinary levels of precipitation occur but at infrequent intervals. Recognizing this potential skewness, quarterly rainfall distributions were estimated and simulated using the non-normal distribution model developed by Ramirez and McDonald (2006). This statistical model has been shown to accurately replicate any non-normal probability distribution that might be encountered in practice, including the substantial levels of right skewness expected with rainfall distributions. Using long-term (1914-2006) Corona, New Mexico, rainfall data (Torell et al. 2008, fig. 2), statistical analysis indicated CRLRC rainfall patterns during the winter months and during the second quarter of the year are substantially right-skewed $(P>0.001)$, whereas summer rainfall was not statistically different from a normal distribution $(P=0.26)$.

While rainfall distributions are of interest and related, in this application we seek a reliable estimate of the probability distribution for mean annual grass yield, not rainfall. A grass yield regression equation relating seasonal rainfall totals to the annual herbaceous standing crop reported by McDaniel et al. (1997, 2000) was estimated using GAUSS constrained maximum likelihood subroutines (Aptech Systems, Inc. 2001). The equation estimated was

$$
\begin{aligned}
Y_{t}= & \underset{(37.18)}{129.88}+\underset{(0.21)}{1.75} \text { WINTER }+\underset{(0.33)}{0.86} Q 2_{t}+\underset{(0.17)}{2.22} Q 3_{t} \\
& -33.96 \mathrm{LNGUSA}_{t} \quad R^{2}=0.31, \quad \text { RMSE }=295
\end{aligned}
$$

* indicates standard error; all parameters were statistically significant at the 0.01 level or higher. $Y_{t}=$ estimated annual herbaceous production $\left(\mathrm{kg} \cdot \mathrm{ha}^{-1}\right)$, WINTER $=$ quarter 4 rain- 
Table 1. Resources and economic characteristics defined in the linear programming model.

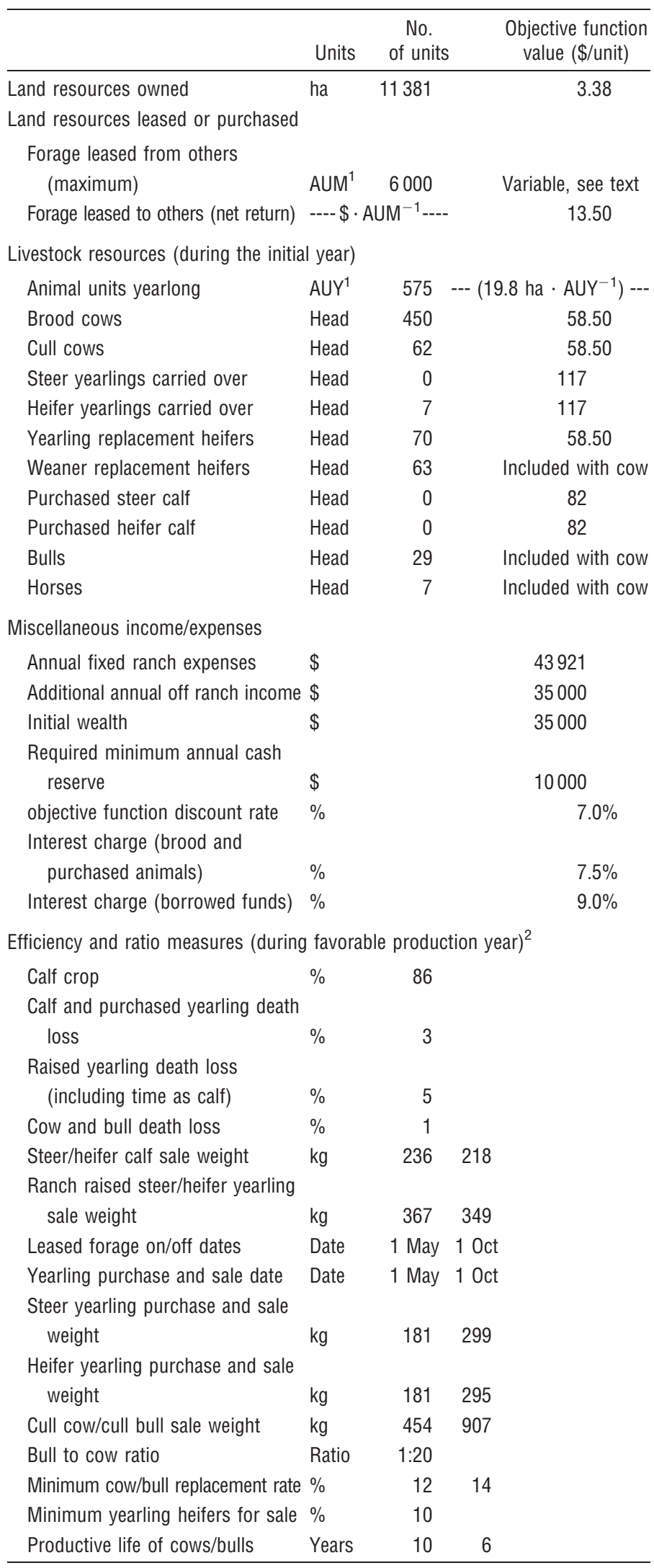

${ }^{1} \mathrm{AUM}$ indicates animal unit months; AUY, animal units yearlong.

${ }^{2} \mathrm{Calf}$ crop was reduced by $5 \%$ and sale weights by $11 \%$ when herbage production was below $451 \mathrm{~kg} \cdot \mathrm{ha}^{-1}$.
Table 2. Average and variation in simulated 2005 real beef prices used in the economic analysis.

\begin{tabular}{|c|c|c|c|c|c|}
\hline \multirow[b]{2}{*}{ Description } & \multirow[b]{2}{*}{ Units } & \multicolumn{4}{|c|}{ Simulated beef prices } \\
\hline & & Average & Min & Max & SD \\
\hline Steer calf $(181 \mathrm{~kg})$ & $\$ \cdot \mathrm{kg}^{-1}$ & 2.35 & 1.25 & 3.50 & 0.40 \\
\hline Heifer calf (181 kg) & $\$ \cdot \mathrm{kg}^{-1}$ & 2.27 & 1.02 & 3.47 & 0.45 \\
\hline Purchased steer calf $(299 \mathrm{~kg})^{1}$ & $\$ \cdot \mathrm{kg}^{-1}$ & 2.09 & 1.24 & 2.96 & 0.32 \\
\hline $\begin{array}{l}\text { Purchased heifer calf } \\
(295 \mathrm{~kg})^{1}\end{array}$ & $\$ \cdot \mathrm{kg}^{-1}$ & 1.98 & 1.22 & 2.75 & 0.31 \\
\hline $\begin{array}{l}\text { Ranch raised steer yearling } \\
\quad(367 \mathrm{~kg})\end{array}$ & $\$ \cdot \mathrm{kg}^{-1}$ & 1.94 & 1.03 & 2.88 & 0.33 \\
\hline $\begin{array}{l}\text { Ranch raised heifer yearling } \\
(349 \mathrm{~kg})\end{array}$ & $\$ \cdot \mathrm{kg}^{-1}$ & 1.97 & 0.88 & 3.01 & 0.39 \\
\hline Cull cow $(454$ kg) & $\$ \cdot \mathrm{kg}^{-1}$ & 0.94 & 0.44 & 1.49 & 0.21 \\
\hline Cull bull (907 kg) & $\$ \cdot \mathrm{kg}^{-1}$ & 1.29 & 0.71 & 1.88 & 0.25 \\
\hline Buy brood cow & $\$ \cdot$ head $^{-1}$ & 925 & 414 & 1567 & 195 \\
\hline Buy bull & $\$ \cdot$ head $^{-1}$ & 2054 & 1004 & 3373 & 401 \\
\hline
\end{tabular}

fall $(\mathrm{mm})$ during the previous year plus quarter 1 rainfall of the current year, $Q_{2 t}=$ quarter 2 rainfall, $Q_{3 t}=$ quarter 3 rainfall, and LNGUSA $\mathrm{L}_{t}=$ natural $\log$ of broom snakeweed $\left(\mathrm{kg} \cdot \mathrm{ha}^{-1}\right)$ present on the area.

In this application we seek a reliable estimate of the probability distribution for mean annual herbaceous production. The estimated rainfall distributions were used for this purpose. Using equation 1 and assuming no broom snakeweed present, 1 million multivariate rainfall draws were taken from the quarterly rainfall distributions and used to incorporate the effect of rainfall uncertainty for a particular year into the probability distribution of annual grass yields. The error term of equation 1 was not included in the simulations because in this case the error captures random variation across study plots, whereas we seek a yield prediction for the mean level of production. Interestingly, although two of the three seasonal rainfall distributions affecting the grass yield distribution were substantially right-skewed, the latter turned out not to show much departure from normality. Theoretically, this is possible because sums of products of non-normal densities are not necessarily non-normally distributed. Thus, based on the distribution analysis and long-term grass yield estimates reported for the CRLRC (McDaniel et al. 1997, 2000), we assumed herbaceous production on the relatively productive blue grama areas of the CRLRC was distributed normally with a mean of $656 \mathrm{~kg} \cdot \mathrm{ha}^{-1}$ and a standard deviation (SD) of $200 \mathrm{~kg} \cdot \mathrm{ha}^{-1}$.

To allow for proper grazing, we modified slightly the stocking rate recommendation of Hart and Carpenter (2005) and required that during favorable production years a minimum of $336 \mathrm{~kg} \cdot \mathrm{ha}^{-1}$ of herbaceous production must remain at the end of the grazing period, whereas during unfavorable years (defined to be when herbaceous production was $1 \mathrm{SD}$ or more below the mean, $<451 \mathrm{~kg} \cdot \mathrm{ha}^{-1}$ ) the required residual was reduced to $224 \mathrm{~kg} \cdot \mathrm{ha}^{-1}$. This modification is consistent with the stocking prescription of Bement (1969). Bement based his grazing recommendation for bluegrama rangelands largely on animal performance. It was 
determined that when about $336 \mathrm{~kg} \cdot \mathrm{ha}^{-1}$ of herbage was left ungrazed, animal production per hectare was at a maximum. Reducing residual amounts below this level diminished animal gain per hectare and per head. Bement suggested that $224 \mathrm{~kg} \cdot \mathrm{ha}^{-1}$ was an acceptable minimum residual, though livestock weights were reduced as residual levels declined. Correspondingly, we assumed an $11 \%$ reduction in sale weights and a reduction in next year's calf crop of $5 \%$ based on research by Bement (1969), Hart et al. (1988), and Wikse et al. (1995).

The LP model considered the stocking rate restriction to be a maximum amount, penalizing livestock production rates during dry years, but allowing downward herd flexibility if economically optimal. Overgrazing (removing herbaceous production to below $224 \mathrm{~kg} \cdot \mathrm{ha}^{-1}$ ) was not allowed and animal forage requirements had to be met in all years.

For each model iteration and year, the annual level of herbaceous production on blue grama-dominated areas was randomly selected from a normal curve with a mean of $656 \mathrm{~kg} \cdot \mathrm{ha}^{-1} \pm 200 \mathrm{SD}$. Rangeland carrying capacity on these relatively productive areas would then average $13.6 \mathrm{ha} \cdot$ animal units yearlong (AUY) ${ }^{-1}$ following the Bement (1969) stocking rule and assuming $363 \mathrm{~kg} \cdot \mathrm{AUM}^{-1}$ (Vallentine 1990). Some pastures on the CRLRC with pinyon-juniper invasion and shallow soils are not this productive. Thus, an index of relative productivity for each of nine pasture units on the ranch was determined based on historically observed forage productivity differences. Annual grass yield estimates were scaled for each pasture by the productivity index (Murugan 2007), and these production differences were incorporated into the economic model. Average carrying capacity was estimated to be 16.7 ha $\cdot \mathrm{AUY}^{-1}$ or $683 \mathrm{AUY}$ across all pastures. Forage harvested before 1 June when warm season grasses substantially begin to grow was transferred from the previous year. Model equations assumed $13 \%$ of transferred forage would be lost over the late dormant season from natural decay (Pieper et al. 1974).

\section{Cattle Equations}

Most New Mexico ranches typically sell calves in the fall. Carrying calves over for sale as yearlings was also considered to be an option in the LP model, as was the option of purchasing yearling stocker cattle. Forage could also be leased to an outside yearling operator. The cow-calf and cow-yearling enterprise options require other animal classes such as bulls, cull cows, and replacement heifers to be produced at fixed ratios (Table 1).

Forage demands were computed using standard animal unit equivalencies for various animal classes (Vallentine 1990). Yearlings were converted to AUY equivalents assuming an animal unit equivalency factor of 0.70 for a 5 -mo grazing period. It was assumed that if forage leasing was economically optimal, outside yearlings and purchased stocker animals would be on the ranch May through September.

The model was initialized at year 1 stocked as a cow-calf ranch with 575 AUY (19.8 ha $\left.\cdot \mathrm{AUY}^{-1}\right)$. After year 1 , cow numbers can only increase by raising additional replacement heifers or by purchasing cows. The dynamic equations of the LP model determine the potential growth of the herd. The minimum number of replacement heifers raised, or cows purchased, must be greater than or equal to a required minimum herd replacement rate ( $12 \%$ of the herd). Retained replacements and cow purchases can exceed this ratio, implying a growth in the cow herd. The decision to buy cows or raise replacements is optimally determined based on relative costs and prices.

\section{Cash Flow Equations}

Cash flow is the final set of constraints considered in the model. Livestock sales, wildlife leases, off-ranch income, and forage leases are potential sources of cash for the ranch. Forage and livestock raising activities use cash at the expense levels shown in Table 1. The included restrictions recognize that each year, net returns from the ranch, off-ranch income, and accumulated wealth must be greater than or equal to calculated production expenses, fixed expenses, loan obligations, and a required $\$ 10000$ cash residual. A frugal and profit maximizing ranch business is considered. It was assumed that half of excess cash from a good year will be transferred forward to cover expenses and cash shortfalls in future years. The $50 \%$ level was chosen without strong justification. Nonlivestock income (i.e., offranch income, wildlife income) in the amount of $\$ 35000 \cdot \mathrm{yr}^{-1}$ was also assumed to be available to meet cash shortfalls. Funds could be borrowed if a cash shortfall situation arose at a $9 \%$ annual interest rate. Any funds borrowed had to be repaid during the next year, though repeat borrowing could occur for a number of years. Borrowing was not allowed during the last year, and all loan obligations had to be paid in full by the end of the 40-yr planning horizon.

\section{Scenario Definition}

The economic comparison of stocking rate strategies was evaluated as alternative model scenarios that impose different levels of grazing use restrictions and different sets of forage replacement alternatives and costs. Analyzing various specifications of the economic model provided inferences about profit maximizing strategies for adjusting to and managing variability in annual forage production and beef prices. It also provided a way to evaluate the economic importance of maintaining grazing flexibility. Results are described as averages computed across the 100 different beef price and forage situations. Beef prices and herbaceous production were different for each year and iteration but the same across scenarios.

We evaluated two alternative upper stocking rates. First we considered the conservative stocking recommendation of Holochek et al. (2004, p. 253) whereby the maximum annual stocking rate cannot exceed $18.5 \mathrm{ha} \cdot \mathrm{AUY}^{-1}$, which is $90 \%$ of average grazing capacity for the CRLRC. For this conservative stocking strategy, we evaluated production and economic differences when only a cow-calf enterprise (scenario 1) was considered versus the situation where multiple enterprises were included (scenario 2), including cow-calf, yearling purchase, yearling carryover, and leasing forage to others. Further, to compute economic costs and consequences from unavoidable annual forage variability, we included and compared the situation where the SD of forage production was reduced to zero (scenario 3). The second stocking rate level considered was a "flexible" scenario with no upper stocking limit specified. 
Table 3. Scenario descriptions.

\begin{tabular}{|c|c|c|c|}
\hline Scenario & Allowed upper stocking rate ${ }^{1}$ & Forage variability & Livestock enterprises allowed \\
\hline 1 & $\begin{array}{l}\text { Conservative } 90 \% \text { of carrying capacity }\left(18.5 \mathrm{ha} \cdot \mathrm{AUY}^{-1}\right. \\
\text { or } 615 \text { AUY total) }\end{array}$ & $\begin{array}{l}\text { Variable and distributed normally with a mean of } \\
656 \mathrm{~kg} \cdot \mathrm{ha}^{-1} \pm 200 \mathrm{SD}\end{array}$ & Cow/calf only \\
\hline 2 & $\begin{array}{l}\text { Conservative } 90 \% \text { of carrying capacity }\left(18.5 \mathrm{ha} \cdot \mathrm{AUY}^{-1}\right. \\
\text { or } 615 \text { AUY total) }\end{array}$ & $\begin{array}{l}\text { Variable and distributed normally with a mean of } \\
656 \mathrm{~kg} \cdot \mathrm{ha}^{-1} \pm 200 \mathrm{SD}\end{array}$ & Cow/calf and yearling enterprises \\
\hline 3 & $\begin{array}{l}\text { Conservative } 90 \% \text { of carrying capacity }\left(18.5 \text { ha } \cdot \mathrm{AUY}^{-1}\right. \\
\text { or } 615 \text { AUY total) }\end{array}$ & Constant $656 \mathrm{~kg} \cdot \mathrm{ha}^{-1}$ & Cow/calf and yearling enterprises \\
\hline 4 & Flexible as determined by profitability & $\begin{array}{l}\text { Variable and distributed normally with a mean of } \\
656 \mathrm{~kg} \cdot \mathrm{ha}^{-1} \pm 200 \mathrm{SD}\end{array}$ & Cow/calf only \\
\hline 5 & Flexible as determined by profitability & $\begin{array}{l}\text { Variable and distributed normally with a mean of } \\
656 \mathrm{~kg} \cdot \mathrm{ha}^{-1} \pm 200 \mathrm{SD}\end{array}$ & Cow/calf and yearling enterprises \\
\hline
\end{tabular}

${ }^{1} \mathrm{AUY}$ indicates animal units yearlong.

Two enterprise options were considered: cow-calf (scenario 4) and multiple enterprises (scenario 5). In all cases herd size was flexible downwards and forage leasing options were included. The scenarios considered are summarized in Table 3.

\section{RESULTS}

Table 4 summarizes key solution values for the various scenarios where averages are computed over the 100 different beef price and forage situations. Some results were similar across all scenarios. First, some brood cows would be purchased during selective favorable years to build herd size, but for the most part the cow herd was maintained by retaining replacement heifers. Purchasing yearlings and leasing forage to an outside yearling operator never occurred in the same year. Leasing forage occurred when the difference between the buy and sell price for purchased yearlings was wide. This is because the profitability of purchased stocker animals decreases as the price spread increases, and leasing forage is more economical in these years. When yearling steers or heifers were purchased, it was most profitable to purchase steers $88 \%$ of the time. However, this does not consider the potential flexibility of saving purchased heifer calves as brood cows if favorable conditions continue.

It was never profitable to carry weaned calves over the winter and sell them the following fall as yearlings with assumed production rates and costs. We assumed relatively little livestock gain over the winter, and model results indicate selling weaned calves in the fall and purchasing outside yearlings the following spring would be more economical. These livestock purchases increase financial risk, however.

Very little borrowing $(<3.5 \%$ of the years $)$ would be required given the assumption that the ranch has $\$ 35000 \cdot \mathrm{yr}^{-1}$ in offranch income to help pay expenses and when following conservative cash management. Off-ranch income was important for meeting cash flow requirements. When this income was excluded, cash flow requirements could not be met for the cowcalf enterprise in about $16 \%$ of iterations.

\section{Scenario 1: Conservative Cow-Calf}

Under the cow-calf only scenario, annual undiscounted net livestock returns averaged $\$ 55126$ or $\$ 102 \cdot \mathrm{AUY}^{-1}$ (Table 4). This would represent a rate of return similar to the $2 \%$ to $3 \%$ historically found for range livestock producers (Torell et al. 2001).

Herd reductions below the maximum allowed 615 AUY occurred during dry, low forage production years and especially when a series of dry years occurred together. Economic returns and the timing of herd adjustments depended on beef prices and forage availability as defined for various model iterations. As an example, consider results for two randomly selected iterations (iteration 3 and iteration 11; Fig. 1). Iteration 3 had 6 of $40 \mathrm{yr}$ where herbaceous production was below the defined $451 \mathrm{~kg} \cdot \mathrm{ha}^{-1}$ cutoff point described earlier, and the required herbage residual was reduced in these years. Because of drought, the optimal strategy was to sell about half the herd at two different times during the 40-yr planning horizon (Fig. 1A). The optimal strategy would keep cow numbers relatively low for an additional $7 \mathrm{yr}$ following the drought that occurred in year 14 . The herd would build back to maximum numbers again in year 21 using saved replacements and purchase of 105 additional brood cows. Dry conditions returned during year 26 but this time forage would optimally be leased to maintain the cow herd. Drought occurred during years 29 and 31 and herd size would once again optimally be reduced.

Iteration 11 had a sustained drought during years 13 through 18 (Fig. 1B). The ranch would have no grazing capacity at all during year 13 with herbaceous production below the required $224 \mathrm{~kg} \cdot \mathrm{ha}^{-1}$ residual. Herd size would be reduced to $223 \mathrm{AUY}$ with total dependence on leased forage at $\$ 50 \cdot \mathrm{AUM}^{-1}$ for remaining animals. Optimal herd size would gradually increase again to the maximum allowed over the next $6 \mathrm{yr}$ by saving additional replacement heifers and by purchasing cows in years 16 and 20. With the assumed normal distribution for forage production, this no-grazing capacity situation would be expected to occur about $1.5 \%$ of the time.

Measured across all years, an average of 703 AUM of forage was leased each year, but forage leasing only occurred in onethird of the years. Averaged for only those years, 2131 AUM of forage were leased when needed (Table 4).

Negative returns occurred $22 \%$ of the time and were primarily associated with below average forage production. When herbaceous production was at least $1 \mathrm{SD}$ below the mean, average undiscounted net returns were $-\$ 68742$ as compared to $+\$ 75248$ during years when it was above this level. Reduced economic returns carried over for several years with reduced herd sizes and the cost of rebuilding the herd. 
Table 4. Summary of scenario results for economic variables, herd sizes, and forage use.

\begin{tabular}{|c|c|c|c|c|c|c|}
\hline & \multirow[b]{3}{*}{ Units } & \multicolumn{5}{|c|}{ Scenario } \\
\hline & & \multicolumn{3}{|c|}{$\begin{array}{l}\text { Conservative upper stocking rate } \\
\text { allowed: } 615 \mathrm{AUY}^{1}\end{array}$} & \multicolumn{2}{|c|}{$\begin{array}{l}\text { Flexible upper stocking rate } \\
\text { allowed: no } \max \end{array}$} \\
\hline & & 1 & 2 & 3 & 4 & 5 \\
\hline Enterprises allowed ${ }^{2}$ & & Cow-calf & Multiple & Multiple & Cow-calf & Multiple \\
\hline Forage variability (SD) ${ }^{3}$ & & 200 & 200 & 0 & 200 & 200 \\
\hline \multicolumn{7}{|l|}{ Land, forage use, and optimal average herd size } \\
\hline Optimal average total AUY & AUY & 541 & 537 & 615 & 682 & 870 \\
\hline Optimal average cow herd AUY & AUY & 541 & 270 & 518 & 682 & 213 \\
\hline Optimal average yearling AUY ${ }^{4}$ & AUY & 0 & 267 & 97 & 0 & 657 \\
\hline Percent of forage allocated to cow/calf & $\%$ & 100 & 50 & 84 & 100 & 24 \\
\hline Harvested rangeland (out of 11381 ha) & ha & 8190 & 8447 & 10236 & 9308 & 10779 \\
\hline Average stocking rate on CRLRC rangeland & ha $\cdot A U Y^{-1}$ & 23.6 & 22.7 & 18.5 & 20.2 & 16.7 \\
\hline Percent of years forage was leased from others & $\%$ & 33 & 22 & 0 & 47 & 44 \\
\hline Forage leased from others (when leased) & AUMs & 2131 & 1894 & 0 & 3066 & 4789 \\
\hline Percent of years forage was leased to others & $\%$ & 0 & 26 & 20 & 0 & 24 \\
\hline Forage leased to others (when leased) & AUMs & 0 & 3535 & 1527 & 0 & 6937 \\
\hline Percent of years yearlings were purchased & $\%$ & 0 & 55 & 60 & 0 & 54 \\
\hline Number of yearlings purchased (when purchased) & Head & 0 & 1198 & 414 & 0 & 3263 \\
\hline \multicolumn{7}{|l|}{ Economic variables } \\
\hline Annual gross sales & \$ total & 192229 & 520803 & 345959 & 240790 & 1224941 \\
\hline Variable costs & \$ total & 93182 & 413805 & 201032 & 127349 & 1065799 \\
\hline Total costs ${ }^{5}$ & $\$$ total & 137103 & 457726 & 244953 & 171270 & 1109720 \\
\hline \multicolumn{7}{|l|}{ Annual net returns } \\
\hline Average & $\$$ total & 55126 & 63076 & 101006 & 69520 & 115221 \\
\hline Average & $\$ \cdot A U Y^{-1}$ & 102 & 117 & 164 & 102 & 132 \\
\hline SD & \$ total & 79855 & 70719 & 47265 & 109580 & 165104 \\
\hline Frequency of negative & $\%$ & 22 & 18 & 0.2 & 26 & 25 \\
\hline Objective function value & $\$$ & 765870 & 928501 & 1351567 & 881147 & 1583865 \\
\hline Percent of years with borrowing & $\%$ & 3.5 & 0.5 & 0.0 & 3.3 & 0.6 \\
\hline $\begin{array}{l}\text { Average amount borrowed (when borrowing } \\
\text { occurred) }\end{array}$ & $\$$ total & 40911 & 16589 & 0 & 44027 & 19542 \\
\hline
\end{tabular}

${ }^{1} \mathrm{AUY}$ indicates animal units yearlong.

${ }^{2}$ Cow-calf $=$ only cow-calf enterprise option included; multiple = options of cow-calf, purchased yearlings, and leasing of forage to an outside yearling operator included.

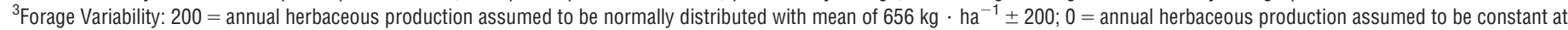
$656 \mathrm{~kg} \cdot \mathrm{ha}^{-1}$.

${ }^{4}$ Includes purchased yearlings and forage leased to an outside yearling operator.

${ }^{5}$ Includes forage harvest and lease costs, animal production costs, loan repayment costs, and fixed costs.

The biggest economic limitation of the conservative cow-calf stocking strategy considered as scenario 1 is that much forage remains unused during favorable years. As an average, only 8190 ha of the total 11381 ha on the ranch would be required to provide forage for the cow herd when conservatively stocked as a cow-calf ranch (Table 4).

\section{Scenario 2: Conservative Multiple Livestock Enterprises}

Adding yearling enterprise alternatives increased the discounted NPV of ranch earnings by $21 \%$ because the added grazing flexibility provided the ability to capture underutilized grazing capacity. Production expenses were over three times as much with the added cost of purchasing stocker animals (Table 4), implying a higher level of financial risk. Negative annual returns occurred $18 \%$ of the time under this scenario.

Dry years largely determined the changing mix between the cow-calf enterprise and yearling enterprises over time. Con- sider once again iterations 3 and 11 . With multiple enterprises and considering iteration 3 (Fig. 2A), the model ranch would optimally maintain the cow herd with minimal yearling purchases until the drought realized during year 14. In years 13 and 14, the cow herd would be sold down to 192 AUY with only a minimal rebuilding in future years. Across all iterations, a 50:50 split of forage would be allocated between the cow-calf enterprise and yearling enterprises (Table 4), but this ratio would diminish over time as the model gradually switched to yearling production when dry years forced herd reductions (Fig. 2C). By the 35th year, no cows were left on the ranch in $59 \%$ of the iterations. Because cow numbers always decreased from the initial level, additional analysis is presented below about optimal herd mix with alternative assumptions.

\section{Scenario 3: Conservative No Forage Variability}

Comparing net returns between scenario 3 and scenario 2 demonstrates the economic consequences of realizing unavoid- 


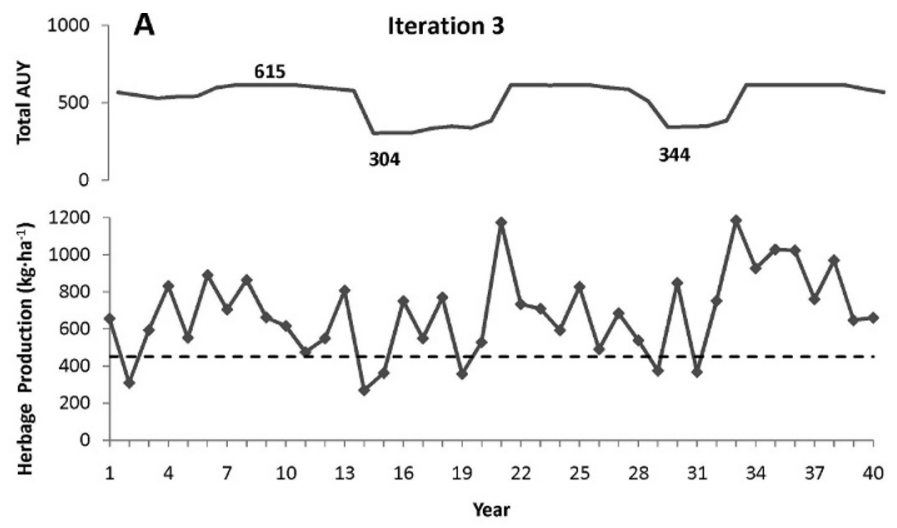

A

Iteration 3

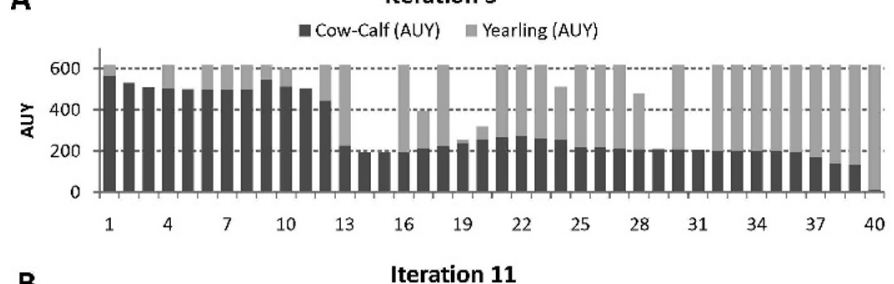

B

Iteration 11

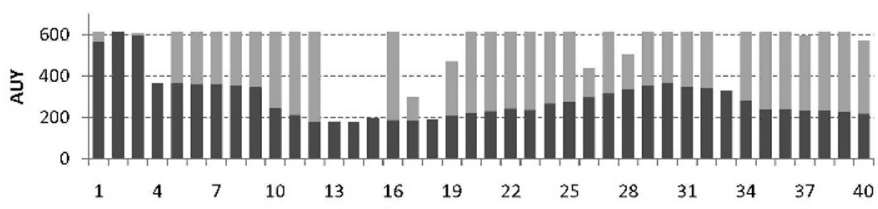

C

All Iterations
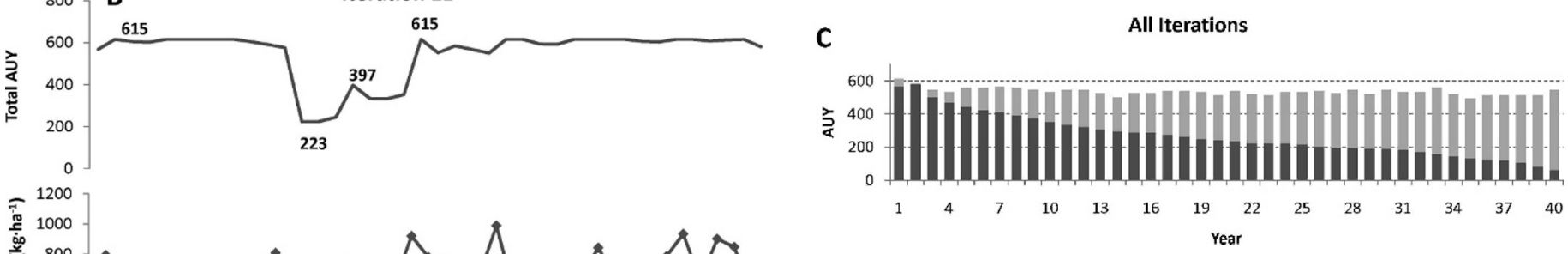

Figure 2. Optimal herd size adjustments to variable forage conditions for selected iterations when managed with cow-calf and yearling enterprises. AUY indicates animal units yearlong.

682 AUY (Table 4). Considering only ranch-raised forage, the cow herd would exceed the defined maximum conservative level $42 \%$ of the time.

Taking advantage of favorable forage production years by eliminating the artificially imposed upper stocking limit would increase average net annual returns to $\$ 69520$ (scenario 4) compared to $\$ 55126$ with conservative grazing (scenario 1). Maintaining and adding to the cow herd would require leased outside forage in $47 \%$ of the years, and $23 \%$ of those years would be during what was defined to be drought years, requiring a $\$ 50 \cdot \mathrm{AUM}^{-1}$ payment on an average 3400 leased AUM.

tion where annual forage production is variable. Variah in annual net returns, as measured by the SD, decreased by $33 \%$ and negative annual returns were nearly eliminated.

Without forage production variability, the allowed maximum stocking rate was economically optimal in all years. A mix of enterprises was optimal, but the ranch would be most reliant on a cow-calf enterprise. An average of $84 \%$ of the forage would be allocated to the cow-calf enterprise across all years with a gradual decrease in cow numbers only after year 30 .

With no annual forage variability, yearling enterprises provide the flexibility to fully utilize available forage on the ranch. With a restricted upper herd size, outside forage would never be leased, because forage demands could always be met with ranch-raised forage. The only unused grazing areas would be relatively unproductive pastures during low beef price years.

\section{Scenario 4: Flexible Cow-Calf}

As defined by Campbell et al. (2006, p. 76), a tracking strategy is one that "attempts to follow the carrying capacity of the land." When this flexible policy was modeled, but with only a cow-calf enterprise considered, the average stocking rate of the ranch would be $20.2 \mathrm{ha} \cdot \mathrm{AUY}^{-1}$ or $563 \mathrm{AUY}(82 \%$ of estimated average capacity). Leased forage would be used to support an additional 119 AUY for a total average herd size of

\section{Scenario 5: Flexible Multiple Enterprises}

With the added flexibility of yearlings on the ranch and with no limit set on stocking rate, all grass up to the required residual amount would be harvested each year. The ranch would fully utilize forage resources and take full advantage of favorable production years while avoiding problems during dry periods by not purchasing outside yearlings. Yearlings would be purchased or forage leased to others in $78 \%$ of the iterations.

Without an upper limit specified, leased forage was important for both drought management and herd expansion. Optimal average herd size would be 870 AUY with 177 AUY of grazing provided from leased outside forage. The optimal stocking rate for only the rangeland acreages on the CRLRC would be the estimated average carrying capacity, 16.7 ha $\mathrm{AUY}^{-1}$. Annual stocking rates would vary widely about this mean, however, with annual levels of grazing use following the assumed normal distribution. As with scenario 2, there would be an increasing allocation of forage to yearlings over time. As an average, 657 AUY of yearlings would be purchased (Table 4). With a 0.70 AU equivalency and a 5-mo grazing season, this is 2252 purchased yearlings per year. 


\section{Sensitivity Analysis}

Additional model scenarios were considered to evaluate alternative management options, but the results are not presented in detail. Specifically, when multiple enterprises where considered as scenario 2 and when the model ranch started with a near capacity cow herd, results indicated a gradual switch to yearlings would optimally occur whenever dry conditions force herd reductions. For scenario 2, over the 40-yr planning horizon, the average forage allocation was found to be a 50:50 split between the cow herd and yearling enterprises (Table 4). Two obvious questions arise: 1) how different would the results be if the ranch stocked cows at $50 \%$ of capacity to begin with? and 2) given the ranch is initially not stocked with breeding animals, would cows, yearlings, or both optimally be purchased? For the first question, it very much matters whether a flexible yearling enterprise is included as a grazing option. As a cow calf ranch only, reducing allowable stocking rates to $50 \%$ of capacity would reduce discounted NPV from $\$ 765870$ (Table 4; scenario 1) to $\$ 555612$, a $27 \%$ reduction. This is consistent with the findings of Martin (1975) and Riechers et al. (1989), where profits were found to increase as allowed stocking rates increased, up to at least the average capacity. But, if the cow herd is set at the conservative $50 \%$ rate and an optimal number of additional yearlings are purchased each year, discounted NPV changed little, decreasing to $\$ 746843$ (only a $2 \%$ reduction relative to scenario 1 ).

Starting with no breeding animals means additional investments must initially be made to purchase cows and bulls. If the ranch started with no cows, the cow herd would gradually be built to average about 100 AUY by year 20 and with a gradual decrease again for the rest of the 40-yr production period. Beef price and forage situations would result in optimal cow herd sizes above 300 AUY for only 5 out of the 100 iterations. Over all years and iterations, $67 \%$ of grazing capacity would be allocated to yearlings for the conservative stocking option. Discounted NPV would be $\$ 632443$ and average annual undiscounted returns would be $\$ 49567$.

The optimal mix of purchased yearlings to cows obviously depends on the assumed production costs for each enterprise. Animal purchase costs and interest charges varied with the 100 alternative price situations, but we also included an additional $\$ 82 \cdot$ head $^{-1}$ expense for each yearling purchased for things like supplement, salt, labor, veterinary expenses, hauling, etc. (Murugan 2007, table 6). If this production expense increases, ceteris paribus, the optimal ratio of yearlings to cows will decrease. We conducted a sensitivity analysis to evaluate the cost influence using scenario 2 as the comparison. With a $10 \%$ increase in yearling expense, total AUY on the ranch would remain at 537 AUY, but the proportion of forage allocated to yearlings would decrease from $50 \%$ to $34 \%$. The forage allocation to yearlings would decline still further to $24 \%$ if yearling production costs increased by $20 \%$. Results were sensitive to relative production costs but robust over a wide range. If there were no forage variability (scenario 3 ) and yearling costs increased $20 \%$, only $3 \%$ of the forage would be allocated to the yearling enterprise. Clearly, yearlings are in the optimal mix, not because they are more profitable but rather because in a dynamic situation they provide a relatively lowcost way to adjust to variable forage conditions.

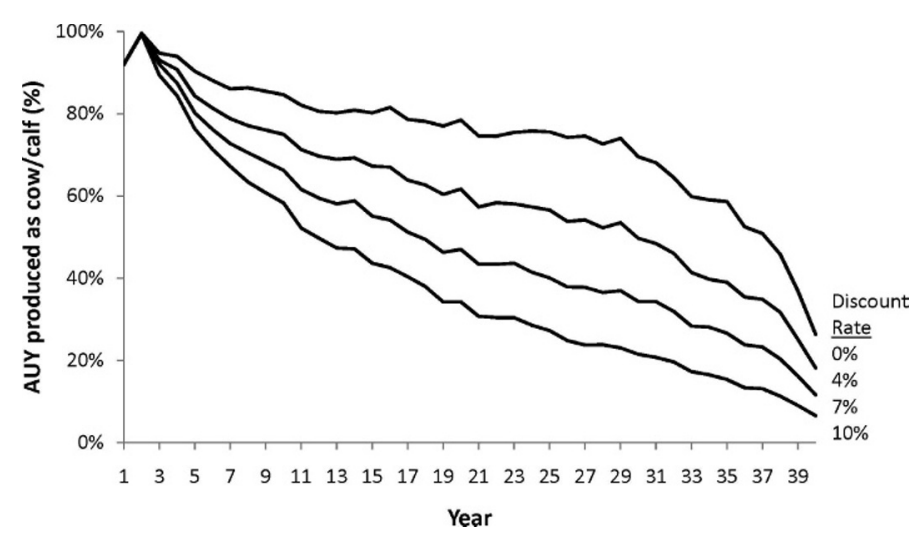

Figure 3. Optimal allocation of forage to cow-calf production at alternative discount rates. AUY indicates animal units yearlong.

Alternative discount rates of $0 \%, 4 \%, 7 \%$, and $10 \%$ were evaluated for scenario 2 . Average undiscounted annual returns changed very little, ranging from \$65 484 with a zero discount rate to $\$ 61083$ at a $10 \%$ rate. The discounted objective function value ranged from $\$ 2.62$ million with a $0 \%$ discount rate to $\$ 0.709$ million with a $10 \%$ rate. The average allocation of forage to the cow-calf enterprise was $74 \%$ at a $0 \%$ discount rate, and increasing the discount rate hastened the switch to yearlings (Fig. 3). With a $10 \%$ discount rate, an average of $41 \%$ of forage would be allocated to the cow herd, but as before, the allocation would diminish over time. At low discount rates, the relative economic advantage of the cowcalf enterprise justified maintaining the cow herd as compared to switching to yearlings and realizing lower economic returns in subsequent years. Higher future economic returns potentially realized by maintaining the cow herd had more value at a lower discount rate.

\section{DISCUSSION}

Despite the deterministic nature of the linear programming model used here, this work highlights the potential economic payoff from following established drought management strategies. Most notable is the importance of allocating a significant part of forage production to a flexible yearling enterprise. Hart and Carpenter (2005) recommend that no more than $50 \%$ to $70 \%$ of total carrying capacity should be allocated to the cow herd. Using a $7 \%$ discount rate, we found a 50:50 split of forage between the cow-calf enterprise and yearling enterprises to be optimal when following a conservative grazing strategy, assuming the ranch is initially stocked as a cow-calf ranch. We found the desired average forage allocation to be within the Hart and Carpenter recommended range under varied economic situations.

The economic importance of maintaining grazing flexibility increased with increasing forage production variability. When there was no forage variability, $84 \%$ of available forage would optimally be allocated to the cow herd. When forage conditions were variable, dry years force reductions in cow numbers, and it takes a number of years to increase cash flow and rebuild the cow herd. It was economically best to gradually switch to yearling production as drought years forced herd reductions, and for many price situations the cow herd would not be rebuilt. 
Undoubtedly there are some rangeland areas where annual herbaceous production is so variable it would be best to raise only yearlings.

Maintaining grazing flexibility means additional costs and financial risks. With conservative stocking, average annual net ranch returns increased by $14 \%$ when the flexible yearling enterprise was included, but gross sales and production costs increased by over 2.7 times to realize this net return difference. This increased expense and financial risk may not justify the added net returns for risk-averse individuals.

Flexible grazing may have its greatest potential for northern climates where cool season perennial grasses dominate and the majority of herbaceous production occurs early in the spring. Spring precipitation is a good predictor of total annual forage production in this case (Andales et al. 2006), and ranch managers have some basis upon which to make sound forage forecasts and stocking decisions. For the shortgrass prairie where this research was conducted, warm-season grasses predominate and substantial herbaceous production does not occur until June and July (Pieper et al. 1974). Stocker purchase decisions must still be made in March and April based only on the amount of carry-over forage remaining from the previous year, a 90-d seasonal forecast available from the National Weather Service Climate Prediction Center (2010), and perhaps an intuitive feeling for what forage conditions will be. The substantial payoff we estimate from successfully adopting a flexible grazing strategy represents a potential that would require a perfect climate and forage forecast. This perfect forecast would allow full utilization of forage resources and potential annual net ranch returns would nearly double (Table 4; scenario 5). With 11381 ha on the study ranch, this amounts to a $\$ 4.58 \mathrm{ha}^{-1} \cdot \mathrm{yr}^{-1}$ potential increase in annual net returns. A perfect forage forecast would be worth up to this maximum amount. Improved forecasts would also potentially yield positive economic returns. Yet, without a very accurate forecast, livestock producers may largely be forced to follow the substantially less economical conservative stocking strategy.

Climate forecasts have largely been ignored by livestock producers for stocking decisions, because they are too uncertain and cover regions that are too broad (Ash et al. 2000; Jochec et al. 2001; Luseno et al. 2003). Mjelde et al. (1988) show that the economic value of an improved climate forecast can be estimated as the difference in expected net returns with and without the forecast. It requires a decision model describing how prior expectations about future forage conditions are improved with a forecast. Using a forecast to improve stocking rate decisions will only be beneficial if the net benefits from the forecast outweigh costs from errors caused by an incorrect forecast, including both missed opportunities for actions and actions taken inappropriately (Stafford Smith et al. 2000). The economic value of the forecast will depend primarily on accuracy and lead time (Mjelde et al. 1988). Further, Jochec et al. (2001) estimate that very little price discount between destocked and restocked animals can exist for cow-calf producers to beneficially adapt using forage forecasts. Our dynamic analysis supports this conclusion. In many cases favorable restock prices did not occur for a number of years following the drought-forced destock.

\section{IMPLICATIONS}

This research demonstrates that areas with high levels of precipitation (forage) variability must maintain a high degree of grazing flexibility for economic success and many areas have limited economic potential for cow-calf production because of widely fluctuating forage conditions. When favorable forage conditions obviously exist with high amounts of carryover forage and observed favorable early-season moisture, adding animals has substantial economic potential for increasing ranch profitability. But herd expansion must largely occur with yearlings to be profitable because adjusting cow numbers to match forage conditions is too expensive relative to potential short-term gains, and this is true even when forage conditions are known with certainty. Harvestable forage must in fact be harvested to have economic value, unless remaining forage improves future productivity. Accurate climate forecasts would increase the precision of planning decisions and increase the potential economic value of flexible grazing strategies. A drawback, however, is that flexible grazing strategies are expensive with substantial costs to purchase yearling animals and this increases financial risk.

\section{ACKNOWLEDGMENTS}

We thank Derek Bailey, Neil Rimbey, and Brian Hurd, who provided review and insight on early drafts of this paper. We also thank Editor Dave Briske, Associate Editor Urs Kreuter, and three anonymous reviewers for their helpful comments and suggestions. Input and assistance from Shad Cox and other staff at the Corona Range and Livestock Research Center is also appreciated.

\section{LITERATURE CITED}

Agricultural and Applied Economics Association. 2000. Commodity costs and returns estimation handbook. Ames, IA, USA: A Report of the AAEA Task Force on Commodity Costs and Returns. 566 p. Available at: http://www.economics. nrcs.usda.gov/care/Aaea/. Accessed 25 November 2009.

Agricultural Marketing Resource Center. 2007. Livestock price risk management links. Available at: http://www.agmrc.org/business_development/operating_ a_business/risk_management/livestock_price_risk_management.cfm. Accessed 10 July 2009.

Andales, A. A., J. D. Derner, L. R. Ahuja, and R. H. Hart. 2006. Strategic and tactical prediction of forage production in northern mixed-grass prairie. Rangeland Ecology and Management 59:576-584.

APTECH Systems, Inc. 2001. Constrained maximum likelihood estimation for GAUSS, version 2.0. Black Diamond, WA, USA: Aptech Systems, Inc. 164 p. Available at: http://www.aptech.com. Accessed 2 June 2010.

Ash, A., P. O'Reagain, G. McKeon, and M. Stafford Smith. 2000. Managing climate variability in grazing enterprises: a case study of dalrymple shire, northeastern Australia. In: G. L. Hammer, N. Nicholls, and C. Mitchell [EDs.]. Applications of seasonal climate forecasting in agricultural and natural ecosystems: the Australian experience. Dordrecht, The Netherlands: Kluwer Academic. p. 253-270.

BEment, R. E. 1969. A stocking-rate guide for beef production on blue-grama range. Journal of Range Management 22:83-86.

Brooke, A., D. Kendrick, A. Meeraus, and R. Raman. 2005. Gams: a user's guide. Washington, DC, USA: GAMS Development Corporation. 262 p.

Campbell, B. M., D. Dore, M. Luckert, B. Mukamuri, and J. Gambiza. 2000. Economic comparisons of livestock production in communal grazing lands in Zimbabwe. Ecological Economics 33:413-438. 
Campbell, B. M., I. J. Gordon, M. K. Luckert, L. Petheram, and S. Vetter. 2006. In search of optimal stocking regimes in semi-arid grazing lands: one size does not fit all. Ecological Economics 60:75-85.

Hart, C. R., and B. B. Carpenter. 2005. Stocking rate and grazing management. College Station, TX, USA: Texas Agricultural Extension Serivce E-64. 3 p.

Hart, R. H., J. W. Waggoner, JR., T. G. Dunn, C. C. Kaltenbach, and L. D. Adams. 1988. Optimal stocking rate for cow-calf enterprises on native range and complementary improved pastures. Journal of Range Management 41:435441.

Holechek, J., R. D. Pieper, and C. H. Herbel. 2004. Range management: principles and practices. Upper Saddle River, NJ, USA: Prentice Hall. 607 p.

Jochec, K. G., J. W. Muelde, A. C. Lee, and J. R. Conner. 2001. Use of seasonal climate forecasts in rangeland-based livestock operations in west Texas. Journal of Applied Meteorology 40:1629-1639.

Luseno, W. K., J. G. McPeak, C. B. Barrett, P. D. Little, and G. Gebru. 2003. Assessing the value of climate forecast information for pastoralists: evidence from southern Ethiopia and northern Kenya. World Development (Oxford) 31:1477-1494.

MARousek, G. 2005. Budgeting value-added beef production for specialty markets. Moscow, ID, USA: University of Idaho Research Bulletin 796. 38 p.

MARTIN, S. C. 1975. Stocking strategies and net cattle sales on semi-desert range. Fort Collins, CO, USA: US Department of Agriculture, Rocky Mountain Forest and Range Experiment Station Research Paper RM-146. 10 p.

McDaniel, K. C., D. B. Carroll, and C. R. Hart. 2000. Broom snakeweed establishment following fire and herbicide treatments. Journal of Range Management 53:239-245.

McDaniel, K. C., C. R. Hart, and D. B. Carroll. 1997. Broom snakeweed control with fire on new mexico blue grama rangeland. Journal of Range Management 50:652-659.

McGrann, J. 1996. Irm-spa handbook cow-calf enterprise standardized performance analysis (spa) measures \& summary description. College Station, TX, USA: Texas A\&M University SPA-11. 10 p.

Muelde, J. W., S. T. Sonka, B. L. Dixon, and P. J. Lamb. 1988. Valuing forecast characteristics in a dynamic agricultural production system. American Journal of Agricultural Economics 70:674-684.

Murugan, S. 2007. Profit maximizing livestock production and marketing strategies to manage climate variability [thesis]. Las Cruces, NM, USA: New Mexico State University. 107 p.

National Weather Service Climate Prediction Center. 2010. Climate prediction center: outlooks index. Available at: http://www.cpc.ncep.noaa.gov/products/OUTLOOKS_ index.shtml. Accessed 2 June 2010.

Pieper, R. D., C. H. Herbel, D. D. Dwyer, and R. E. Banner. 1974. Management implications of herbage weight changes on native rangeland. Journal of Soil and Water Conservation 29:227-229.

RamiRez, O. A., AND T. U. McDonald. 2006. The expanded johnson system: a highly flexible crop yield distribution model. American Economics Association 2006 Annual Meeting; Long Beach, CA. 31 p. Available at: http://purl.umn.edu/ 21455. Accessed 30 December 2009.

Riechers, R. K., J. R. Conner, and R. K. Heitschmidt. 1989. Economic consequences of alternative stocking rate adjustment tactics: a simulation approach. Journal of Range Management 42:165-171.

Smathers, R. L., AND N. R. RImBey. 2006. Stocker-200 head no wintering, bought in spring, sold in fall. Moscow, ID, USA: University of Idaho Cooperative
Extension Service 2006 Cost and Return Series EBB-ST3-06. 4 p. Available at: http://www.ag.uidaho.edu/aers/PDF/Livestock/EEB\%202004/EBB-ST3-06.pdf. Accessed 30 December 2009.

Sneva, F. A., and D. N. Hyder. 1962. Estimating herbage production on semiarid ranges in the intermountain region. Journal of Range Management 15:88-93.

StAFFORD Smith, D. M. 1992. Stocking rate strategies across Australia: or, how do you cope with drought? The Australian Rangeland Society Range Management Newsletter 92:1-3.

Stafford Smith, M., R. Buxton, G. McKeon, and A. Ash. 2000. Seasonal climate forecasting and the management of rangelands: do production benefits translate into enterprise profits? In: G. L. Hammer, N. Nicholls, and C. Mitchell [EDS.]. Applications of seasonal climate forecasting in agricultural and natural ecosystems: the Australian experience. Dordrecht, The Netherlands: Kluwer Academic Publishers. p. 271-289.

Stillings, A. M., J. A. Tanaka, N. R. Rimbey, T. Delcurto, P. A. Momont, and M. L. Porath. 2003. Economic implications of off-stream water developments to improve riparian grazing. Journal of Range Management 56:418-424.

Tanaka, J. A., N. R. Rimbey, L. A. Torell, D. T. Taylor, D. Bailey, T. Delcurto, K. Walburger, and B. Welling. 2007. Grazing distribution: the quest for the silver bullet. Rangelands 29:38-46.

Torell, L. A., K. C. McDaniel, S. Cox, and S. Majumdar. 2008. Eighteen years (19902007) of climatological data on NMSU's corona range and livestock research center. Las Cruces, NM, USA: New Mexico State University Agricultural Experiment Station Research Report 761. 20 p. Available at: http://agecon. nmsu.edu/corona. Accessed 2 June 2010.

Torell, L. A., And N. R. Rimbey. 2005. Factors affecting the market value of the NMSU corona ranch. Proceedings, corona range and livestock research center: field day. Las Cruces, NM, USA: New Mexico State University. p. 55-69.

Torell, L. A., N. R. Rimbey, J. A. Tanaka, and S. A. Bailey. 2001. The lack of a profit motive for ranching: implications for policy analysis. In: L. A. Torell, E. T. Bartlett, and R. Larrañaga [EDS.]. Proceedings of the Annual Meeting of the Society for Range Management; 17-23 February 2001; Kailua-Kona, HI, USA. Las Cruces, NM, USA: New Mexico State University, Agricultural Experiment Station, Research Report 737. p. 47-58. Available at: http:// ageconsearch.umn.edu/handle/16629. Accessed 26 November 2009.

Torell, L. A., J. A. Tanaka, N. Rimbey, T. Darden, L. Van Tassell, and A. Harp. 2002. Ranch-level impacts of changing grazing policies on blm land to protect the greater sage-grouse: evidence from Idaho, Nevada, and Oregon. Caldwell, ID, USA: Policy Analysis Center for Western Public Lands (PACWPL) Policy Paper SG-01-02. 20 p. Available at: http://sagemap.wr.usgs.gov/Docs/sage-grouse econ.pdf. Accessed 30 December 2009.

Torell, L. A., W. Van Tassell, N. R. Rimbey, E. T. Bartlett, T. Bagwell, P. Burgener, AND J. COEN. 1993. The value of public land forage and the implications for grazing fee policy. Las Cruces, NM, USA: New Mexico State University Agricultural Experiment Station, Research Bulletin 767. 63 p.

Vallentine, J. F. 1990. Grazing management. San Diego, CA, USA: Academic Press. $533 \mathrm{p}$.

Wikse, S. E., D. B. Herd, R. W. Field, P. S. Holland, J. M. McGrann, J. A. Thompson, C. White, and R. Angerstein. 1995. Use of performance ratios to calculate the economic impact of thin cows in a beef cattle herd. Journal of the American Veterinary Medical Association 207:1292-1297. 